\title{
IDENTIFICATION OF BACTERIA ASSOCIATED WITH LOWER RESPIRATORY TRACT AMONG PATIENTS ATTENDING IN GENERAL HOSPITAL DR. PIRNGADI MEDAN
}

\author{
JEFRI NALDI ${ }^{1 *}$, ROSIDAH ROSIDAH ${ }^{1}$, RICKE LOESNIHARI $^{2}$
}

${ }^{1}$ Department of Pharmacology, Faculty of Pharmacy, University of Sumatera Utara, Medan, Indonesia. ${ }^{2}$ Department of Clinical Pathology, Faculty of Medicine, University of Sumatera Utara, Medan, Indonesia. Email: jefri_naldi03@yahoo.com

Received: 16 April 2018, Revised and Accepted: 18 May 2018

\section{ABSTRACT}

Objective: The aim of this study was to establish cases of bacteria associated with lower respiratory tract infections (LRTIs) in General Hospital Dr. Pirngadi Medan with the view to identify the bacteria well as to assess their antibiotics susceptibility.

Methods: An observation and prospective study were analyzed to patients with lower respiratory tract infection in respiratory and internal wards Dr. Pirngadi Hospital Medan. For the identification method of bacteria was using optochin test, catalase test, Mannitol salt agar, coagulase, indole, methyl red, Voges-Proskauer test, citrate, urease, and Triple Sugar Iron test.

Results: The bacteria that cause lower respiratory tract infection were Pseudomonas aeruginosa (25.53\%), Klebsiella pneumoniae (17.02\%), Proteus sp. (14.89\%), Staphylococcus aureus (12.77\%), Escherichia coli (10.64\%), Streptococcus pneumoniae (10.64\%), and Haemophilus influenzae (8.51\%). The result of sensitivity testing showed that gentamicin is more sensitive and the resistant antibiotic is chloramphenicol among all the tested antibiotics.

Conclusion: P. aeruginosa was the most common isolated from LRTIs patients with gentamicin is the most sensitive antibiotics while chloramphenicol is the most resistant antibiotics among all the tested antibiotics.

Keywords: Bacteria, Antibiotic, Lower respiratory tract infection, Susceptibility.

(C) 2018 The Authors. Published by Innovare Academic Sciences Pvt Ltd. This is an open access article under the CC BY license (http://creativecommons. org/licenses/by/4. 0/) DOI: http://dx.doi.org/10.22159/ajpcr.2018.v11i9.26722

\section{INTRODUCTION}

Infection of the respiratory system is a common disease in the community. Respiratory infections based on the region of the infection are divided into upper respiratory infections and lower respiratory tract infections (LRTIs). In general, the cause of respiratory tract infections is various microorganisms, but the most are due to bacterial and viral infections. The mortality rate is very high in baby, children, elderly, and especially in countries with low- and medium-income per capita [1]. LRTIs are among the most common infectious diseases affecting humans worldwide [2]. They are important causes of morbidity and mortality for all age groups, and each year approximately 7 million people die as a direct consequence of acute and chronic respiratory infections [3].

The World Health Organization report in 2012 said that LRTIs, especially pneumonia rank fourth as the leading cause of death in the world and at the same time, the leading cause of death from infectious diseases class [4]. In research conducted in RSUP. H. Adam Malik Medan found that around $50 \%$ of bacterium Streptococcus viridans and Streptococcus pneumonia (14.6-20\%) isolated from sputum, while Gram-negative bacteria obtained Klebsiella pneumonia, Pseudomonas, and Escherichia coli [5].

One of the fastest growing treatments is treated with antibiotics. This drug is able to cope with various types of infectious diseases caused by bacteria. The high use of antibiotics of more than one type and in the long term generally used for handling complications of severe infections in hospitals is one of the factors triggering the occurrence of bacterial resistance [6]. Bacterial resistance is one of the world's problems. Every year the number of resistant bacteria always increases. The United States alone recorded at least 2 million people got the disease with the bacteria that have been resistant to some antibiotics, and about 23,000 people died from the bacteria resistant [7]. In some Asian countries such as China, Taiwan, Hong Kong, the Philippines, and Singapore found the prevalence of bacteria such as Staphylococcus aureus which has been resistant to some antibiotics is high, with prevalence rates in China (20\%), Taiwan (60\%), Hong Kong (70\%), The Philippines $(5 \%)$, and Singapore $(60 \%)$. Some bacteria other than $S$. aureus, such as E. coli, Klebsiella spp., Serratia spp., Citrobacter freundii, and Morganella spp. also show a fairly high rate of resistance [8].

Current knowledge of the organisms that cause LRTIs and their antibiotic susceptibility profiles are therefore necessary for the prescription of appropriate therapy [9]. Changes in the characteristics of the population as it ages and the swelling numbers of patients with immunocompromising conditions have increased the number of individuals at risk [2]. The clinical laboratory plays a key role in the diagnosis of these infections with lots of challenges due to the complexity of LRTIs including quality of specimen and diversity; contamination of specimens with oropharyngeal flora; a diverse pathogen population that includes bacteria, viruses, and fungi; and the complex pathophysiology of respiratory tract infections [10]. There are numerous organisms causing LRTI including bacteria, fungi, and viruses. Diagnosis of LRTIs is often missed or misdiagnosed due to the procedures involved. The aim of this study was to establish cases of bacteria associated with LRTIs in General Hospital Dr. Pirngadi Medan with the view to identify the bacteria well as to assess their antibiotics susceptibility.

\section{METHODS}

Study area

This study was conducted in General Hospital Dr. Pirngadi Medan between September and December 2016. The samples in this study were those that met the inclusion and exclusion criteria. The inclusion criteria of the study are the patient with a clinical diagnosis is a lower respiratory tract infection, adult patients (over 18 years), and patients 


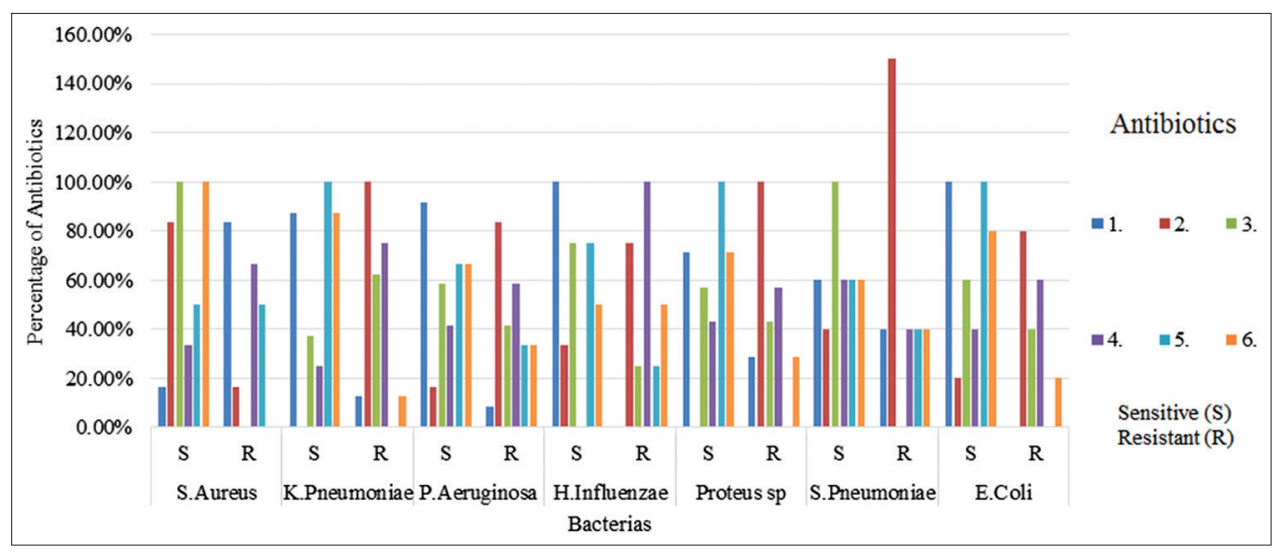

Fig. 1: Sensitivity of bacteria that cause lower respiratory tract infections against antibiotics

Table 1: Inhibitory zones for some antibiotics [15]

\begin{tabular}{|c|c|c|c|c|}
\hline \multirow[t]{2}{*}{ Antibiotics } & \multirow[t]{2}{*}{ Antibiotics amount $(\mu \mathrm{g})$} & \multicolumn{3}{|c|}{ Diameter zona (mm) } \\
\hline & & Resistant & Intermediate & Sensitif \\
\hline Ceftriaxone & 30 & $0-13$ & $14-20$ & $\geq 21$ \\
\hline Amoxicillin & $20 / 10$ & $0-13$ & $14-17$ & $\geq 18$ \\
\hline Ampicillin & 10 & $0-13$ & $14-16$ & $\geq 17$ \\
\hline Cefotaxime & 30 & $0-14$ & $15-22$ & $\geq 23$ \\
\hline Cotrimoxazole & $1.25 / 23.7$ & $0-10$ & $11-15$ & $\geq 16$ \\
\hline Tetracycline & 30 & $0-14$ & $15-18$ & $\geq 19$ \\
\hline Ceftazidime & 30 & $0-14$ & $15-17$ & $\geq 18$ \\
\hline Meropenem & 10 & $0-13$ & $14-15$ & $\geq 16$ \\
\hline Amikacin & 30 & $0-14$ & $15-16$ & $\geq 17$ \\
\hline Gentamicin & 10 & $0-6$ & $7-8$ & $\geq 9$ \\
\hline Ciprofloxacin & 5 & $0-15$ & $16-20$ & $\geq 21$ \\
\hline Aztreonam & 30 & $0-15$ & $16-21$ & $\geq 22$ \\
\hline
\end{tabular}

Table 2: Percentage of bacterial cause for LRTIs

\begin{tabular}{ll}
\hline Bacteria & Count (\%) \\
\hline Pseudomonas aeruginosa & $12(25.53)$ \\
Klebsiella pneumoniae & $8(17.02)$ \\
Proteus sp. & $7(14.89)$ \\
Staphylococcus aureus & $6(12.77)$ \\
Escherichia coli & $5(10.64)$ \\
Streptococcus pneumonia & $5(10.64)$ \\
Haemophilus influenza & $4(8.51)$ \\
Total & $47(100.00)$ \\
\hline
\end{tabular}

LRTIs: Lower respiratory tract infections

with LRTIs undergoing treatment with antibiotics of one type or more of one type of antibiotic. The exclusion criteria are the patients who are not willing to participate in the study. Recent study resulted that only 47 patients included as inclusion criteria from 100 patients respondent.

\section{Sample collection}

Early morning sputum specimens were aseptically collected into appropriate sterile containers from 47 patients who are willing for taking their sputum. Each container was clearly labeled with sex and age of the patient and transported to the laboratory.

\section{Microbiological analysis}

The samples were cultured on blood agar and MacConkey agar plates. The plates were then incubated at $37^{\circ} \mathrm{C}$ for $24 \mathrm{~h}$. Gram staining was carried out to differentiate the bacteria into Gram positive and Gram negative [11].

\section{Identification}

Organisms isolated were identified through various biochemical tests. These include optochin test, catalase test, Mannitol salt agar, coagulase, indole, methyl-red, Voges-Proskauer test, citrate, urease, and Triple Sugar Iron test.

\section{Antibiotic susceptibility testing}

Test of bacterial susceptibility to antibiotics was done by disc diffusion method. This method is performed using a filter paper disc containing a certain amount of antibiotics placed on the surface of a solid medium (blood agar) that has been inoculated with bacteria. Then, it is incubated at $37^{\circ} \mathrm{C}$ for $18-24 \mathrm{~h}$. Futher observations were made by observing the inhibition zone. Clear areas/zones indicate the absence of bacterial growth. Measurements are made using the sliding or antibiotic zone reader. The result of bacterial sensitive or resistant to antibiotics will ke known by comparing the diameters of clear areas(inhibition zone) with standar tables performed by Clinical Laboratory Standards Institute (CLSI). The following Table 1 showed the inhibitory zone of antibiotics according to CLSI [12-14].

\section{RESULTS AND DISCUSSION}

From the screening results, from 47 patients, the majority of causes of LRTIs are Gram-negative bacteria. Distribution of bacteria in patients with LRTIs is 36 Gram-negative bacteria and 11 Gram-positive bacteria. Bacteria that cause LRTIs are shown in Table 2. The most common bacteria found as a cause of LRTIs is Pseudomonas aeruginosa. Overall, the largest percentage of bacteria that cause LRTIs were P. aeruginosa $25.53 \%$, Klebsiella pneumoniae $17.02 \%$, Proteus sp. $14.89 \%$, S. aureus $12.77 \%$, E. coli $10.64 \%$, Streptococcus pneumoniae $10.64 \%$, and Haemophilus influenzae $8.51 \%$. 




According to Setyati and Murni in General Hospital Dr. Sardjito Yogyakarta found bacteria that cause pneumonia which is Grampositive group as much as $39.3 \%$ and Gram negative as much as $60.6 \%$. P. aeruginosa was the most common bacteria (39.3\%), followed by K. pneumoniae (19.1\%). While comparing to Kumala research at the Clinical Microbiology Laboratory of Faculty of Medicine University of Indonesia in 2010, the most common cause of LRTIs are Gram-negative bacteria (95\%) consisting of K. pneumoniae $(23 \%)$ and P. aeruginosa (11\%), while Gram-positive bacteria are only $5 \%$. This proves that the bacteria that cause LRTIs in this study are similar $[16,17]$.

Table 3 and Fig. 1 showed that the percentage of susceptibility values of bacterial LRTIs against antibiotics. In the table, it is seen that gentamycin is the most sensitive antibiotic to bacteria that LRTIs. Gentamicin was more sensitive (78.72\%) than with other antibiotics such as amikacin (76.60\%), meropenem (74.47\%), cefotaxime (65.96\%). Antibiotics that started to be resistant to bacteria that cause LRTIs are chloramphenicol (36.17\%) and followed by ampicillin (23.40\%).

From the results of the sensitivity test of bacteria that cause LRTIs against some antibiotics (Table 3), S. aureus bacteria have good sensitivity to cefotaxime $(100 \%)$ and meropenem $(100 \%)$, but $S$. aureus bacteria begin to resist the amikacin (16.67\%) and chloramphenicol (33.33\%). The bacteria K. pneumoniae have good sensitivity to gentamicin (100\%), meropenem $(87.5 \%)$, and amikacin $(87.5 \%)$, but these bacteria were resistant to ampicillin $(0 \%)$ and chloramphenicol $(25 \%)$ antibiotics. P. aeruginosa bacteria were sensitive to amikacin (91.67\%), gentamicin (66.67\%), and meropenem (66.67\%), and P. aeruginosa was resistant to ampicillin (16.67\%) and chloramphenicol (41.67\%).

Then, for $H$. influenzae bacteria had good sensitivity to amikacin $(100 \%)$, cefotaxime $(75 \%)$, gentamicin $(75 \%)$ but already resistant to ampicillin antibiotics (33.33\%) and chloramphenicol (0\%). Proteus sp. was sensitive to gentamicin (100\%), amikacin (71.43\%), meropenem (71.43\%), and cefotaxime (57.14\%) and resistant to chloramphenicol $(42.86 \%)$ and ampicillin (0\%). S. pneumonia bacteria have sensitivity to cefotaxime $(100 \%)$, amikacin $(60 \%)$, chloramphenicol $(60 \%)$, gentamicin (60\%), meropenem (60\%), and begin to resist ampicillin (40\%). E. coli bacteria had the highest sensitivity to amikacin (100\%), gentamicin $(100 \%)$, meropenem $(80 \%)$, and cefotaxime $(60 \%)$. E. coli was resistant to ampicillin (20\%) and chloramphenicol (40\%). Factors that facilitate the development of resistance in hospitals are the continuous use of antibiotics, the use of irrational antibiotics, long-term use of antibiotics, poor sexual, and sanitary (hygiene) behaviors [18].

\section{CONCLUSION}

Based on the results of identification of bacteria causing LRTIs were P. aeruginosa 12 samples (25.53\%), K. pneumoniae 8 samples (17.02\%), Proteus sp. 7 samples (14.89\%), S. aureus 6 samples $(12.77 \%)$, E. coli 5 samples (10.64\%), S. pneumoniae 5 samples (10.64\%), and H. influenzae 4 samples (8.51\%). Antibiotics with the highest sensitivity to bacteria that cause LRTIs were gentamicin (78.72\%), followed by amikacin $(76.60 \%)$, meropenem $(74.47 \%)$, and cefotaxime $(65.96 \%)$. Antibiotics that have low sensitivity to bacteria that cause LRTIs are ampicillin (23.40\%) and chloramphenicol (36.17\%).

\section{ACKNOWLEDGMENTS}

This work was supported by Faculty of Pharmacy, Universitas Sumatera Utara.

\section{AUTHOR'S CONTRIBUTION}

All the authors have contributed equally.

\section{CONFLICTS OF INTEREST}

We declare that we have no any conflicts of interest. 


\section{REFERENCES}

1. The Indonesia Department of Health. 50 Main Rank Disease Pattern at Hospital in Indonesia. Jakarta, Indonesia: The Indonesia Department of Health; 2005.

2. Carroll KC. Laboratory diagnosis of lower respiratory tract infection. J Clin Microbiol 2002;40:3115-20.

3. Ozyilmaz E, Akan OA, Gulhan M, Ahmed K, Nagatake T. Major bacteria of community-acquired respiratory tract infections in turkey. Jpn J Infect Dis 2005;58:50-2.

4. World Health Organization. The World Health Report. Washington, USA: World Health Organization; 2014.

5. Parhusip RS. Identification of Bacteria in Lower Respiratory Tract System; 2005. Available from: http://www.library.usu.ac.id/download/ fk/paru-parhusip3.pdf.

6. Blot S, Vandewoude K, De Bacquer D, Colardyn F. Nosocomial bacteremia caused by antibiotic-resistant gram-negative bacteria in critically ill patients: Clinical outcome and length of hospitalization. Clin Infect Dis 2002;34:1600-6.

7. Centers for Disease Control and Prevention. Antibiotic Prescribing; 2014. Available from: http://www.cdc.gov/media/releases/2014/p0304poor-antibioticprescribing.html.

8. Mardiastuti HW, Karuniawati A, Kiranasari A. Emerging resistance pathogen: The current situation in Asian, Europe, United states, middle east and Indonesia. Majalah Kedokteran Indonesia 2007;57:75-9.

9. Egbe CA, Ndiokwere C, Omoregie R. Microbial of lower respiratory tract infections in Benin city, Nigeria. Malays J Med Sci 2011;2:135-42.
10. Campbell S, Forbes BA. The clinical microbiology laboratory in the diagnosis of lower respiratory tract infections. J Clin Microbiol 2011;49:30-3

11. Cheesbrough M. District Laboratory Practice in Tropical Countries Part Two. $2^{\text {nd }}$ ed. United Kingdom: Cambridge University Press; 2006.

12. CLSI-Clinical Laboratories Standards Institute. Performance Standards for Antimicrobial Susceptibility Testing; Sixteenth Informational Supplement. Wayne, PA: CLSI; 2006.

13. Mwambete KD, Stephen WS. Antimicrobial resistance profiles of bacteria isolated from chicken droppings in dar es salaam. Int J Pharm Pharm Sci 2015;7:268-71.

14. Pooja MB, Sweta SR, Sheela KD, Dileep KV. Characterization of carbapenem resistant Acinetobacter baumannii isolated in a tertiary care hospital: Epideminology and 'atment outcome. Int J Pharm Pharm Sci 2016;8:277-81

15. Brooks GF, Butel JS, Carroll CK, Morse SA, Jawetz J, Melnick M, et al. Medical Microbiology. Jakarta (Indonesia): EGC Publisher; 2008.

16. Setyati A, Murni IK. Pneumonia infectious patient patterns at inpatient installations RSUP dr. Sardjito Yogyakarta. Med Medika Indones 2011;46:195-200.

17. Kumala S, Dimas AM, Mardiastuti M. Antibiotic resistance against bacterial isolates from sputum patients with lower respiratory tract infections. Indones J Pharm 2010;5:24-32.

18. Brunton L, Parker K, Blumenthal D, Buxton I. Goodman and Gilman's Manual Pharmacology and Applied. Jakarta (Indonesia): EGC Publisher; 2008. 